\title{
United Kingdom: Mineral Policy
}

\author{
J. M. Mankelow and C. E. Wrighton
}

Mineral Resources and Policy Team, British Geological Survey, Keyworth, Nottingham. UK.

\section{General Information on the United Kingdom}

The United Kingdom consists of Great Britain (England, Scotland and Wales) and Northern Ireland and occupies an area of approximately 244,000 $\mathrm{km}^{2}$. It has a population of 64.1 million (2013) [Office for National Statistics (ONS), 2014a] which is predicted to grow to over 73 million by 2037 and 86 million by 2087 [ONS, 2014b]. Onshore and offshore mineral production contributed $£ 34$ billion, or two per cent, to UK Gross Domestic Product (GDP) in 2012. Table 1 summarises 2013 population and economic statistics for countries of the UK.

Table 1 Population and GDP statistics for countries of the UK

\begin{tabular}{|c|r|r|}
\hline Country & $\begin{array}{c}\text { Population 2013 } \\
\text { (million) }\end{array}$ & $\begin{array}{c}\text { GVA 2013 } \\
\text { (£ per capita) }\end{array}$ \\
\hline United Kingdom - of which & $\mathbf{6 4 . 1}$ & $\mathbf{2 0 ~ 8 7 3}$ \\
\hline England & 53.9 & 24091 \\
\hline Northern Ireland & 1.8 & 17948 \\
\hline Scotland & 5.3 & 21982 \\
\hline Wales & 3.1 & 16893 \\
\hline
\end{tabular}

GVA - Gross Value Added, is the difference between the value of the output (e.g sales revenue) and the cost of bought-in inputs used to produce it (fuel and other raw materials, but not labour). There is a close link between GVA and GDP.

Source: Office for National Statistics, licensed under the Open Government Licence v.3.0.

The UK is fortunate in having both abundant and a wide range of indigenous mineral resources, and their extraction and use have played an important role in the development of the economy. Detailed information on individual minerals can be found in a series of Mineral Planning Factsheets [British Geological Survey, various]. These provide succinct overviews of each of the economically important minerals extracted onshore in Britain, including relevant planning policy and regulation.

With the exception of oil, gas, coal, gold and silver, the state does not own mineral rights in the UK. The mineral rights to gold and silver in most of the UK are owned by the Crown and managed by the Crown Estate. The right to exploit minerals in the foreshore and on the seabed within the limits of national jurisdiction is also vested in the Crown and, apart from oil, gas and coal, these resources are also managed by the Crown Estate. Mineral rights for other commodities are generally held in private ownership, and information on mineral rights, where available, is held by the Land Registry together with details of land surface ownership.

\section{Need for minerals}

The UK has an economically important minerals industry, with oil, gas, and construction being the dominant sectors by tonnage (Table 2 ) and value (Table 3). The UK produces a wide range of construction minerals - aggregates (from both onshore and offshore), brick clay, cement-making raw materials, gypsum, building stone and slate and a number of industrial minerals - kaolin, ball clay, silica sand, potash, industrial carbonates, fluorspar and barytes. Many of these minerals support downstream, value-added industries, and some, like kaolin, ball clay and potash, also serve important export markets. Moreover, the UK's onshore mineral potential still attracts interest, such as the current development of a world class tungsten deposit in Devon (Drakelands Mine), proposals for a 
new potash mine in the North York Moors National Park and the ongoing evaluation of the nation's shale hydrocarbon potential [UK Minerals Forum, 2014a].

Minerals are the largest material flow in the UK economy. In 2012 the minerals industry extracted some 290 million tonnes of saleable material (Table 2) of which 190 million tonnes was from onshore. The total value of minerals extracted, on an ex-works basis, was some $£ 34$ billion (Table 3).

Table 2 Production of major sectors of the minerals industry in the United Kingdom, 2008 - 2012

\begin{tabular}{|c|c|c|c|c|c|}
\hline & \multicolumn{5}{|c|}{ Production (thousand tonnes) } \\
\hline & 2008 & 2009 & 2010 & 2011 & 2012 \\
\hline Energy minerals - of which & 153231 & 140431 & 133650 & 112487 & 98033 \\
\hline Coal & 18054 & 17874 & 18416 & 18627 & 17047 \\
\hline Oil, including natural gas liquids (a) & 65497 & 62820 & 58047 & 48571 & 42052 \\
\hline Natural gas (a) & 69680 & 59737 & 57187 & 45289 & 38934 \\
\hline Construction minerals - of which & 236833 & 187695 & 174223 & 184731 & 169169 \\
\hline Primary aggregates & 213469 & 170852 & 155903 & 165915 & 151425 \\
\hline Other construction minerals & 23364 & 16843 & 18320 & 18816 & 17744 \\
\hline Industrial minerals & 24112 & 19470 & 22856 & 23144 & 22437 \\
\hline Metallic minerals (b) & $\mathbf{0}$ & $\mathbf{0}$ & $\mathbf{0}$ & $\mathbf{0}$ & $\mathbf{0}$ \\
\hline Total & 414176 & 347596 & 330729 & 320362 & 289639 \\
\hline
\end{tabular}

(a) Oil equivalent

(b) 0 - small volume

Source: United Kingdom Minerals Yearbook, British Geological Survey (2013)

Table 3 Value of major sectors of the minerals industry in the United Kingdom, 2008-2012

\begin{tabular}{|c|c|c|c|c|c|}
\hline & \multicolumn{5}{|c|}{ Value (£ million) } \\
\hline & 2008 & 2009 & 2010 & 2011 & 2012 \\
\hline Energy minerals - of which & 39072 & 27618 & 31702 & 34810 & 31961 \\
\hline Coal & 1154 & 973 & 1002 & 1345 & 1131 \\
\hline Oil, including natural gas liquids & 27306 & 19075 & 23110 & 25505 & 22975 \\
\hline Natural gas & 10612 & 7570 & 7590 & 7960 & 7855 \\
\hline Construction minerals - of which & 2193 & 1654 & 1684 & 1693 & 1535 \\
\hline Primary aggregates & 1844 & 1425 & 1377 & 1410 & 1279 \\
\hline Other construction minerals & 349 & 229 & 307 & 283 & 256 \\
\hline Industrial minerals & 566 & 935 & 1154 & 1043 & 922 \\
\hline Metallic minerals & 4 & 6 & 10 & 11 & 5 \\
\hline Total & 41835 & 30212 & 34550 & 37557 & 34422 \\
\hline
\end{tabular}

Source: United Kingdom Minerals Yearbook, British Geological Survey (2013)

\section{Overseas Trade}

Despite the significant domestic production set out above, the UK has become increasingly dependent on imports for minerals and minerals-based products, particularly for energy minerals and metals. The move from being a major, long-term, net-exporter of energy minerals (coal, and then oil and gas) to a major importer has been particularly rapid, and with declining offshore reserves of both oil and gas 
this trend is unlikely to be reversed [UK Minerals Forum, 2014b]. Net imports of oil (and oil based products) and gas were £15 244 million in 2012 and those for coal were £3 018 million.

The UK is almost entirely dependent on imports for the supply of metals. One exception is the contribution made by recycled (secondary) metals. Imports of metal ores and scrap were $£ 4198$ million, compared with exports of $£ 4488$ million in 2012, almost all of which was scrap.

The UK is virtually self-sufficient in construction minerals and also produces and exports a number of industrial minerals, notably china clay (kaolin), ball clay, potash and salt. Kaolin is the second most important mineral export after oil. Imports of non-metallic minerals and mineral-based products were $£ 29771$ million and exports were £25 230 million in 2012.

Table 4 summarises UK imports and exports by tonnage for selected minerals.

Table 4 UK imports and exports by tonnage for selected minerals, 2012

\begin{tabular}{|lr|r|r|}
\cline { 2 - 4 } \multicolumn{1}{c|}{} & \multicolumn{3}{c|}{2012} \\
\cline { 2 - 4 } \multicolumn{1}{c|}{} & \multicolumn{1}{c|}{ Imports } & \multicolumn{1}{c|}{ Exports } & Net imports \\
\cline { 2 - 4 } \multicolumn{1}{c|}{} & \multicolumn{3}{c|}{ (thousand tonnes) } \\
\hline Natural gas (oil equivalent) & 46482 & 13651 & 32832 \\
\hline Oil and oil based products & 67012 & 38910 & 28102 \\
\hline Coal & 42099 & 537 & 41561 \\
\hline Sand and gravel & 519 & (a) 4572 & -4053 \\
\hline Crushed rock & 1273 & 4251 & -2978 \\
\hline Ball clay & 8 & 567 & -558 \\
\hline Barytes & 88 & 19 & 69 \\
\hline Cement and cement clinkers & 1667 & 346 & 1321 \\
\hline Kaolin (China clay) & 89 & 1039 & -951 \\
\hline Fluorspar & 20 & (b) 0 & 20 \\
\hline Gypsum (includes plasters) & 538 & 25 & 513 \\
\hline Potash (potassium chloride product) (c) & 161 & 440 & -279 \\
\hline Salt & 418 & 396 & 22 \\
\hline Silica sand & 138 & 88 & 49 \\
\hline Total & $\mathbf{1 6 0} \mathbf{5 1 2}$ & $\mathbf{6 4} \mathbf{8 4 3}$ & $\mathbf{9 5 6 6 9}$ \\
\hline
\end{tabular}
(a) Mainly marine-dredged
(b) 0 - small volume
(c) BGS estimate

Source: United Kingdom Minerals Yearbook, British Geological Survey (2013)

\section{Secondary resources and recycling}

The UK has a good record of increasing the production of recycled (49.2 million tonnes, 2012) and secondary aggregates (11.2 million tonnes, 2012), with the highest consumption (29\% of total aggregates consumption) in Europe [Mineral Products Association, 2013], although effective capacity is now being approached [Waste and Resources Action Programme, 2006]. Other secondary materials utilised within the UK include cementitious materials (pulverised fuel ash and blast furnace slag), desulphogypsum, glass cullet, iron steel and copper scrap and aluminium and lead via secondary production. Total consumption of these other secondary materials was 8.4 million tonnes in 2012 [UK Minerals Forum, 2014a]. 


\section{Classification of mineral reserves}

There is no prescribed use of a particular system of reporting for mineral resources and reserves in the UK. Both the PERC (Pan-European Reserves and Resources Reporting Committee) Standard and Australian JORC Joint Ore Reserves Committee Code are used by the minerals industry in the UK. It is convention in the UK when referring to reserves of non-energy minerals, and particularly primary aggregates, to include only those with a planning permission for extraction.

\section{Mineral policy conception of the United Kingdom}

The central government role in planning is undertaken by the UK Parliament (for England), the Scottish Parliament, the National Assembly for Wales and the Northern Ireland Assembly. This is a result of a transferral of planning powers from the UK Parliament after referendums took place in Scotland and Wales in 1997 and in both Northern Ireland and the Republic of Ireland in 1998. Since 1999, these parliaments and assemblies have had devolved responsibility, to varying degrees, for the production of legislation on planning [Directgov, 2011]. The legislation issued by these bodies determines minerals policy and guidance at a national level. The policies and guidance are subsequently implemented by local planning authorities.

Planning policy for minerals within the UK is concerned with maintaining adequate and steady supplies of those minerals which can be indigenously produced and which support UK economic activity, without unacceptable adverse impacts on the natural and historic environment, amenity or human health [Wrighton et al., 2014].

The winning and working of minerals, whether by surface or underground methods, and including the disposal of mineral waste, requires planning permission (licence to operate). The control of mineral working in the UK is exercised through land-use planning legislation implemented through relevant policy rather than through specific mining legislation. Minerals extraction, which has a number of special characteristics, tends to be treated as a special case, attracting planning controls additional to those in general planning law. Some of these characteristics are:

- minerals can only be worked where they naturally occur and there is a limited choice of location;

- although working may take place over a long period of time, mineral working is not considered as a permanent use of land;

- working may have adverse environmental effects. Sites, therefore, need to be carefully controlled during the process of extraction;

- on cessation of mineral working the land requires treatment to make it suitable for beneficial after-use.

\section{Onshore}

In England, Government policy for minerals is included in the National Planning Policy Framework published by the Department for Communities and Local Government (DCLG) [DCLG, 2012]. Similar policy is provided by the Scottish Government and the Welsh Government. In Scotland the equivalent document is Scottish Planning Policy [Scottish Government, 2014]. In Wales, the relevant policy documents are Planning Policy Wales [Welsh Government, 2016] and Mineral Technical Advice Notes on Aggregates [National Assembly of Wales, 2004] and Coal [National Assembly of 
Wales, 2009]. In Northern Ireland, minerals policy is provided in the Strategic Planning Policy Statement for Northern Ireland [Department of the Environment for Northern Ireland, 2015].

In general, key objectives of mineral policies within the UK are to:

- conserve and safeguard mineral resources from unnecessary sterilisation and secure supplies of the materials needed by society and the economy from environmentally acceptable sources;

- limit the impact of mineral extraction on local communities, the environment and the built and natural heritage;

- promote efficient use and appropriate re-use and recycling of suitable materials, minimising the net requirement for new primary extraction;

- achieve high standards of restoration and beneficial after-use when working has ceased.

\section{Offshore}

Recent legislation has implemented changes to how planning in the UK marine environment is undertaken. The Marine and Coastal Access Act 2009 [HM Government, 2009] and the Marine (Scotland) Act 2010 [Scottish Government, 2010], introduced a new system for marine planning and licensing with a move away from an historically sectoral-based permit system to a more holistic planled one such as applies onshore [Bide, 2013]. For England a new body, the Marine Management Organisation (MMO), has been created and tasked with formulating spatial plans and associated policies. The Scottish Government, Welsh Government and Department of Environment for Northern Ireland are responsible for this in their respective marine areas. These plans, currently being developed will provide detailed policy and associated spatial guidance for marine activities. With regard to marine sand and gravel, the plans should ensure provision for the long-term supply of sand and gravel and take into account the need to safeguard mineral resources from sterilisation by other forms of development [HM Government et al., 2011].

\section{Regulatory framework}

The planning system in the UK is essentially organised through two levels; central government and local government, in the form of local planning authorities [Moore, 2010]. The central government role in planning is undertaken by the UK Parliament (for England), the Welsh Government, Scottish Government, and the Northern Ireland Assembly. The legislation issued by these bodies determines policy and guidance at a national level. The policies and guidance are subsequently implemented by local planning authorities, through documents which set out a plan for development for the authority area and help guide decisions on planning applications.

A local authority with responsibility for mineral planning, including deciding planning applications for a licence to operate, is called a Mineral Planning Authority (MPA). In Wales, Scotland and some parts of England, the responsibility for mineral planning resides with unitary authorities (single tier of local government), which deal with all planning issues within their areas. In those parts of England with two tiers of local government (counties and districts), MPAs are the county councils. In Northern Ireland, local authorities (councils) have responsibility for implementing mineral planning policy and deciding planning applications for a licence to operate.

At the local level the planning system is divided into two fundamental functions:

1. Development planning: this establishes policies and plans to guide future development ('development plans') which will influence decisions on individual site planning applications. Development plans translate central Government policies to the local level. There is a mandatory requirement that all MPAs (in England and Wales) prepare Minerals 
(and Waste) Local Plans, which set out the policies and proposals against which planning applications are determined. Minerals Local Plans are one of a series of documents that form the Development Plan. Similar requirements exist in Scotland and Northern Ireland where local planning authorities are required to incorporate mineral policies in a Local Development Plan.

Development plans are produced through an extensive process of consultation with prospective developers and the general public. They are of increasing importance since there is a presumption in favour of proposals (planning applications) that accord with the development plan unless material considerations indicate otherwise. The planning system is, therefore, plan-led with relevant development plans providing a clear guide to mineral operators and the public where mineral extraction is likely in principle to be acceptable and where not acceptable and thus provide the basis for decisions on individual planning applications. This helps to give certainty to both the minerals industry and local residents in respect of proposals for extraction.

Development plans are reviewed at regular intervals (at least every five years) to assess whether some or all of it may need updating. Such updates are necessary to take account of new information and changing circumstances.

2. Development management: this involves taking decisions on planning applications submitted by prospective mineral developers and enforcing the conditions under which the individual sites proceed. All modern planning permissions have operating and restoration conditions attached so that the cost of meeting environmental standards are met by the operator. Operating conditions are imposed to control the environmental impacts of mineral working, and restoration and aftercare conditions are imposed to ensure that land worked for minerals is suitable for a beneficial after-use.

Key planning documents for England, Scotland, Wales and Northern Ireland are shown in Figure 1.

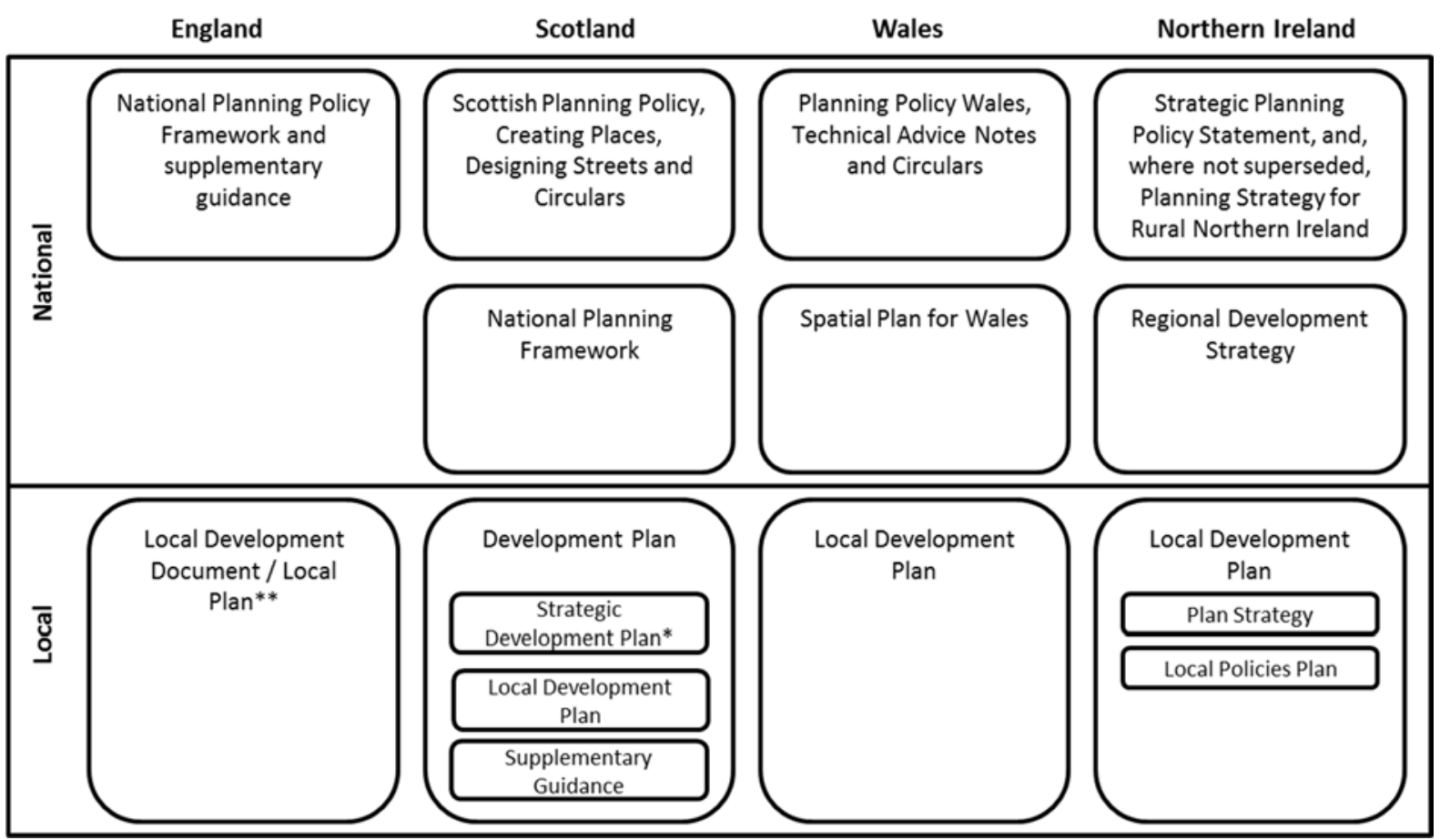


* Largest city regions only

** These may be separate documents or combined in one plan.

Figure 1 Key onshore planning documents in the UK based on Cullingworth and Nadin (2006) and Wrighton et al. (2014)

\section{International memberships}

The UK is a member of the: European Union; G20 International Forum; International Monetary Fund; Organisation for Economic Co-operation and Development; United Nations: United Nations Conference on Trade and Development; World Bank; and World Trade Organisation.

The then UK Prime Minister, Tony Blair, outlined the idea of the Extractive Industries Transparency Initiative (EITI) in a speech intended for the World Summit on Sustainable Development in Johannesburg in September 2002. In 2013, during its presidency of the G8, the UK Government announced it would implement the EITI. Subsequently Government submitted its candidacy application and implementation work plan in August 2014 and since October 2014 the UK has the status of a candidate country. The UK is scheduled to publish its first EITI report by April 2016.

\section{Concluding statement}

Within the UK, management of the nation's finite mineral resources is undertaken through a strategic, plan-led approach. National and local policies for minerals aim to ensure an adequate, steady and secure supply of minerals. The overall aim of mineral planning is, therefore, to meet the justified need for minerals to support the national economy, as far as practicable, at the least social, economic and environmental cost. Wherever possible, areas of designated landscape, nature conservation or heritage value are protected from mineral development.

\section{References}

Bide, T. (2013) Safely acquiring new resources. Mineral Planning. Haymarket Media Group Ltd. Issue 138, p. 8.

British Geological Survey (2013) United Kingdom Minerals Yearbook. Available via: http://www.bgs.ac.uk/mineralsuk/statistics/ukStatistics.html. Accessed 25 April 2015.

British Geological Survey (various) Mineral Planning Factsheets. Available via: http://www.bgs.ac.uk/mineralsuk/planning/mineralPlanningFactsheets.html. Accessed 25 April 2015.

Cullingworth, B. and Nadin,V. (2006) Town and Country Planning in the UK, $14^{\text {th }}$ edition. Routledge, Oxford.

Department of the Environment for Northern Ireland (2015) Strategic Planning Policy Statement for Northern Ireland (SPPS). Available via http://www.planningni.gov.uk/index/policy/spps_28_september_2015-3.pdf. Accessed 05 Apr 2016

Department for Communities and Local Government (DCLG) (2012) National Planning Policy Framework (NPPF). Available via http://www.communities.gov.uk/documents/planningandbuilding/pdf/2116950.pdf. Accessed 25 April 2015. 
Directgov (2011) Devolved government in the UK. Available via http://webarchive.nationalarchives.gov.uk/20121015000000/http://www.direct.gov.uk/en/Government citizensandrights/UKgovernment/Devolvedgovernment/DG 073306. Accessed 25 April 2015.

HM Government (2009) Marine and Coastal Access Act 2009. Available via http://www.legislation.gov.uk/ukpga/2009/23/pdfs/ukpga_20090023_en.pdf. Accessed 25 April 2015.

HM Government, Northern Ireland Executive, Scottish Government and Welsh Assembly Government. (2011) UK Marine Policy Statement. Available via https://www.gov.uk/government/publications/uk-marine-policy-statement. Accessed 25 April 2015.

Mineral Products Association (2013) Sustainable development report. Available via http://www.mineralproducts.org/sustainability/pdfs/2013_MPA_main_SD_report_single.pdf. Accessed 25 April 2015.

Moore, V. (2010) Planning Law. Oxford University Press, Oxford, 689 pp.

National Assembly for Wales (2004) Minerals Technical Advice Note (MTAN) 1: Aggregates. Available via http://gov.wales/docs/desh/policy/040331aggregatesmtanen.pdf. Accessed 25 April 2015.

National Assembly for Wales (2009) Minerals Technical Advice Note (MTAN) 2: Coal. Available via http://gov.wales/docs/desh/policy/090120coalmtanen.pdf. Accessed 25 April 2015.

Office for National Statistics (ONS) (2014a) Population Estimates for UK, England and Wales, Scotland and Northern Ireland, Mid-2013. Available via http://www.ons.gov.uk/ons/rel/popestimate/population-estimates-for-uk--england-and-wales--scotland-and-northernireland/2013/index.html. Accessed 25 April 2015.

Office for National Statistics (ONS) (2014b) National Population Projections, 2012-based Reference Volume: Series PP2. Available via http://www.ons.gov.uk/ons/rel/npp/national-populationprojections/2012-based-reference-volume--series-pp2/index.html. Accessed 25 April 2015.

Scottish Government. (2010) Marine (Scotland) Act 2010. Scottish Government. http://www.legislation.gov.uk/asp/2010/5/pdfs/asp 20100005 en.pdf. Accessed 25 April 2015.

Scottish Government (2014) Scottish Planning Policy. Available via http://www.gov.scot/Resource/0045/00453827.pdf. Accessed 25 April 2015.

UK Minerals Forum (2014a) Future minerals scenarios for the UK. Report of the UK Minerals Forum Working Group on Future Mineral Scenarios for the UK. Available via http://nora.nerc.ac.uk/508896. Accessed 25 April 2015.

UK Minerals Forum (2014b) Trends in UK production of minerals. Report of the UK Minerals Forum Working Group on Future Mineral Scenarios for the UK. Available via http://nora.nerc.ac.uk/508895. Accessed 25 April 2015.

Waste and Resources Action Programme (WRAP). The sustainable use of resources for the production of aggregates in England. Available via http://www2.wrap.org.uk/downloads/WRAP_AGG0059_project_report_final_20.10.06.49589add.333 7.pdf. Accessed 25 April 2015. 
Welsh Government (2016) Planning Policy Wales. Available via

http://gov.wales/docs/desh/publications/160104planning-policy-wales-edition-8-en.pdf. Accessed 05 Apr 2016

Wrighton, C. E., E. J. Bee and J. M. Mankelow (2014) The development and implementation of mineral safeguarding policies at national and local levels in the United Kingdom. Resources Policy v. 14 p. 160-170. Available via http://dx.doi.org/10.1016/j.resourpol.2014.05.006. Accessed 25 April 2015. 